\title{
Two Types of New Natural Materials for Fruit Vinegar in Prunus
}

\section{Plants}

\author{
Han Zhao ${ }^{1}$, Xiaoxing Zhou ${ }^{2}$, Ying Luo ${ }^{1}$, Yanli Huang ${ }^{3}$, Tana Wuyun ${ }^{1}$, Fangdong Li $^{1}$ and Gaopu Zhu ${ }^{1, *}$ \\ ${ }^{1}$ Non-timber Forestry Research and Development Center, Chinese Academy of Forestry, and China Paulownia Research \\ and Development Center, Zhengzhou 450003, China \\ ${ }^{2}$ Administrative Office, Chinese Academy of Forestry, Beijing 100091, China \\ ${ }^{3}$ Henan Province Institute of Landscape Planning and Design Company Limited, Zhengzhou 450045, China \\ Corresponding Email: poog502@163.com
}

\begin{abstract}
To increase Prunus armeniaca $\times P$. sibirica and $P$. domestica $\times P$. armeniaca added value; three natural fruit vinegars were designed. The results showed the nutrition of Prunus domestica $\times$ P. armeniaca cultivar Fengweimeigui vinegar (T1) had high minerals and microelements, especially the $\mathrm{Ca}$ and $\mathrm{Mg}$ reached to the $150.00 \mathrm{mg} / \mathrm{L}, 85.40 \mathrm{mg} / \mathrm{L}$, respectively; the vinegar of Prunus armeniaca $\times$ P. sibirica cultivar Zhongren No.1 (T2) not only have rich Na (2800.00 mg/L), P (123.00 mg/L), but also have plentiful amino acid that content reached to $200.08 \mathrm{mg} / \mathrm{L}$. However, the mixture vinegar (T3) with pulps from Prunus domestica $\times$ P. armeniaca and Prunus armeniaca $\times$ P. sibirica had the middle nutrient contents, but the property was balanced. We therefore conclude that solid fermentation is a suitable method to preserve nutrients and value-added for Prunus plants fruit, and three types vinegars are suitable for different age people, and the difference nutrient contents and typical characteristic indicate that three vinegars are competitive products in market.
\end{abstract}

\section{Introduction}

In general, for fruits, there are nourishing but short shelf life, for nuts, the pulps used discarded. For examples, fruits Prunus domestica $\times$ P. armeniaca cultivar Fengweimeigui is rich nutrient [1-2], but the shelf life only lasting 5-7 d; the pulps of nuts Prunus armeniaca $\times$ P. sibirica cultivar Zhongren No.1 have organic acid, Ca, K, Fe and Se [3] but the pulps is inedible because of sour and bitter. With the food structure development, human interest in the health benefits of functional foods is increasingly. Meanwhile, the farmers hope to add agricultural raw materials value. The both of them expectations are consistent and suitable for future economic trend. For these reasons, we developed the new, functional and special products will help stronger the body and economic recovery. Microbial fermentation have been efficient biocatalysts to make the functional foods, this is a suitable method to solve above problems [3-7]. However, fruits vinegar is not only used as a seasoning but also play important roles, such as antioxidant, digestive, lipid lowering effects, and regulations of blood-pressure, these results in the vinegar can resist or assist cure the imbalanced fat or excess energy intake harm [8-10]. In this paper, based on solid fermentation method to produce fruit vinegar and improve residuum utilization ratio have been explored.

\section{Materials and methods}




\subsection{Sample collection}

Fully ripened and healthy (without diseases and insect pests) Prunus domestica $\times$ P. armeniaca cultivar Fengweimeigui and Prunus armeniaca $\times$ P. sibirica cultivar Zhongren No.1 fruits, whether big or small, were selected from garden of the Experimental Site of Non-timber Forestry Research and Development Center, Chinese Academy of Forestry, Yuanyang County, China, during June 2013 (day temperature $28 \pm 2{ }^{\circ} \mathrm{C}$, night temperature $25 \pm 2^{\circ} \mathrm{C}$ ) (Figure 1). The three treatments were designed including T1, T2 and T3. The T1 and T2 are the pure Prunus armeniaca $\times$ P. sibirica cultivar Zhongren No.1, Prunus domestica $\times$ P. armeniaca cultivar Fengweimeigui, and the T3 is the mixture between Prunus armeniaca $\times$ P. sibirica cultivar Zhongren No.1 and Prunus domestica $\times$ P. armeniaca cultivar Fengweimeigui with weight is $1: 1$ $(\mathrm{w} / \mathrm{w})$ ratio because the pulps carbohydrate of Prunus armeniaca $\times$ P. sibirica cultivar Zhongren No.1 was lower, but the Prunus domestica $\times$ P. armeniaca cultivar Fengweimeigui was higher.

\subsection{Fermentation process}

The idea was solid fermentation. The total included seven stages (Figure 1). First, fruits were cleaned and dried. Second, the fruits were put a closed room and use ultraviolet disinfection with $8 \mathrm{~h} \sim 12 \mathrm{~h}$. Third, the fruits were crushed with machine and became pulp, meanwhile, the seeds was separated with pulp. Fourth, alcoholic fermentation stage including four steps (Figure 1). (a) Based on the preliminary experiment, the weight of saccharose with 2:5 (w/w) was added. (b) The Saccharomyces cerevisiae was added and the ratio is $0.2 \mathrm{~g} / 100 \mathrm{ml}$. (c) The pulps were stirred every $6 \mathrm{~h}$ interval until the saccharose were melted (about 3 times). (d) A stationary culture was conducted for 3 days at $35{ }^{\circ} \mathrm{C}$ in constant-temperature culture medium. The fifth stage, static acetic acid fermentation with three steps. (a) Acetic bacteria were added and the content reached to $1.0 \mathrm{mg} / 100 \mathrm{ml}(\mathrm{w} / \mathrm{v})$. (b) Fermentation at higher temperature at $33 \pm 2{ }^{\circ} \mathrm{C}$ last 5 days. (c) Fermentation at constant lower temperature at $25 \pm 2{ }^{\circ} \mathrm{C}$ last 45 days. After fermentation, the filtration and sterilization was operation. Finally, the bottles were filled with vinegars. The procedure for making fruits vinegars is list in figure 1 .

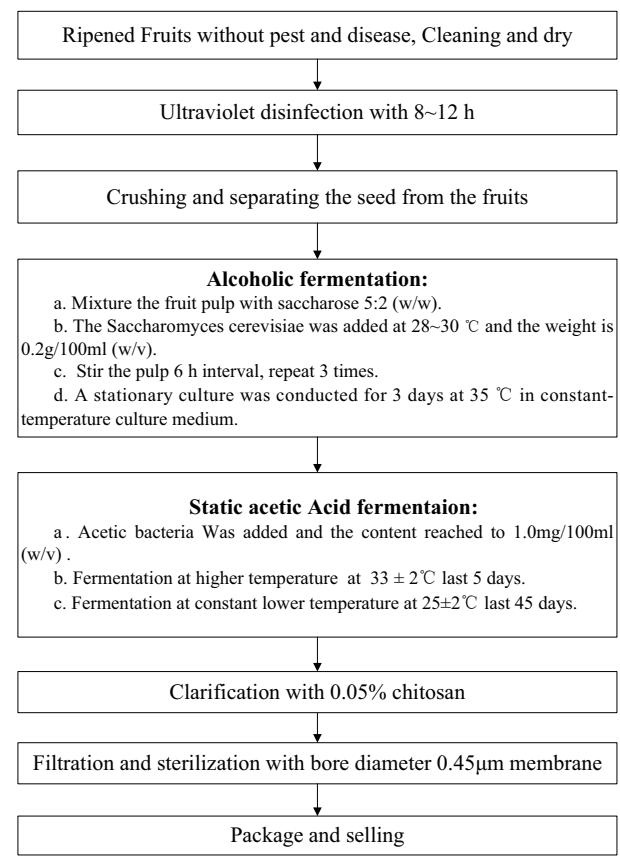

Fig. 1. Procedure for making fruit vinegars. 
The composition and content of amino acid, minerals and microelements, juice $\mathrm{pH}$ value and biochemical constituents (total sugar, total fat, total protein and ethanol) were analyzed based on GB/T 5009.124-2003 (China), GB/T 14924.12-2001 (China) and Ref. (Amerine et al., 1980; Zhu et al. 2015).

\subsection{Data analysis}

The experimental layout was a complete randomized plot with three replicates of five sampled per treatment. The data collect with Microsoft Office Excel 2013 software and the statistic analysis of variance analysis use Duncan's multiple range tests with DPS v6.05 software. Significance was accepted at $p \leq 0.05$.

\section{Results and analysis}

\subsection{The content different of major components}

Table 1. The proximate composition of main nutrition apricot vinegars $(\mathrm{mg} / \mathrm{L})$.

\begin{tabular}{|c|c|c|c|c|c|c|c|c|c|c|}
\hline $\begin{array}{l}\text { Treat } \\
\text { ment }\end{array}$ & Protein & Fat & Sugar & $\mathbf{F e}$ & Mg & $\mathbf{N a}$ & $\mathbf{Z n}$ & $\mathrm{Ca}$ & $\mathbf{P}$ & pH \\
\hline $\mathrm{T} 1$ & $\begin{array}{c}0.12 \pm 0 \\
02 \mathrm{aA}\end{array}$ & $\begin{array}{l}0.01 \pm \\
0.00 \mathrm{a}\end{array}$ & $\frac{138.00 \pm 1}{.70 a A}$ & $\frac{3.30 \pm 0 .}{\underline{16 a A}}$ & $\frac{85.40 \pm 2}{.90 a A}$ & $\begin{array}{c}2600.00 \pm 1 \\
4.84 \mathrm{bB}\end{array}$ & $\frac{1.10 \pm 0 .}{\underline{05 a A}}$ & $\frac{150.00 \pm 3}{.40 a \mathrm{~A}}$ & $\begin{array}{c}63.70 \pm 2 . \\
73 \mathrm{aA}\end{array}$ & $\frac{3.25 \pm 0}{\underline{.02 a}}$ \\
\hline $\mathrm{T} 2$ & $\frac{0.52 \pm 0 .}{\underline{02 c C}}$ & $\begin{array}{l}0.02 \pm \\
0.01 \mathrm{a}\end{array}$ & $\begin{array}{c}76.00 \pm 1 \\
90 \mathrm{cC}\end{array}$ & - & $\begin{array}{c}50.40 \pm 1 \\
.41 \mathrm{cC}\end{array}$ & $\frac{2800.00 \pm 5}{\underline{1.21 a A}}$ & $\begin{array}{c}0.64 \pm 0 \\
04 \mathrm{cB}\end{array}$ & $\begin{array}{c}108.00 \pm 2 \\
.75 \mathrm{cB}\end{array}$ & $\frac{123.00 \pm}{\underline{2.59 b B}}$ & $\begin{array}{c}3.14 \pm 0 \\
.05 \mathrm{a}\end{array}$ \\
\hline $\mathrm{T} 3$ & $\begin{array}{c}0.18 \pm 0 \\
01 \mathrm{bB}\end{array}$ & $\begin{array}{l}0.02 \pm \\
0.00 \mathrm{a}\end{array}$ & $\begin{array}{c}108.00 \pm 2 \\
.30 \mathrm{bB}\end{array}$ & $\begin{array}{c}2.60 \pm 0 . \\
17 \mathrm{bB}\end{array}$ & $\begin{array}{c}78.40 \pm 1 \\
.98 \mathrm{bB}\end{array}$ & $\begin{array}{c}2600.00 \pm 6 \\
.08 \mathrm{bB}\end{array}$ & $\begin{array}{c}0.74 \pm 0 \\
06 \mathrm{bB}\end{array}$ & $\begin{array}{c}143.00 \pm 2 \\
.43 \mathrm{bA}\end{array}$ & $\begin{array}{c}68.20 \pm 2 . \\
56 \mathrm{bB}\end{array}$ & $\begin{array}{c}3.19 \pm 0 \\
.01 \mathrm{a}\end{array}$ \\
\hline
\end{tabular}

Note: values are means $\pm \mathrm{SD}(\mathrm{n}=5)$. Means in columns without letters in common differ significantly $(\mathrm{p}<0.05)$. ND $=$ not detected.

In this study, all the treatments, the contents of protein and fat were lower, but the sugars $138.00 \mathrm{mg} / \mathrm{L}, 76.00 \mathrm{mg} / \mathrm{L}$ and $108.00 \mathrm{mg} / \mathrm{L}$, respectively were higher and the different reached to the significantly (Table 1).

Table 2. The proximate content of essential amino acid in Fengweimeigui wine (mg/ L).

\begin{tabular}{|c|c|c|c|c|c|c|c|c|c|}
\hline $\begin{array}{c}\text { Treatm } \\
\text { ent }\end{array}$ & Lys & Trp & Phe & Met & Thr & Ile & Leu & Val & Total \\
\hline $\mathrm{T} 1$ & $1.8 \pm 0.04 \mathrm{bB}$ & 一 & $1.84 \pm 0.03 \mathrm{bB}$ & $\begin{array}{c}0.16 \pm 0 . \\
01 \mathrm{a}\end{array}$ & $\begin{array}{c}1.11 \pm 0 . \\
03 \mathrm{~b}\end{array}$ & $\begin{array}{c}0.82 \pm 0.03 \\
\text { bB }\end{array}$ & $\begin{array}{c}0.65 \pm 0 \\
05 \mathrm{cC}\end{array}$ & $\begin{array}{c}1.86 \pm 0.09 b \\
B\end{array}$ & $\begin{array}{c}8.24 \pm 0.7 \\
8 \mathrm{bB}\end{array}$ \\
\hline $\mathrm{T} 2$ & $\begin{array}{c}2.58 \pm 0.05 \mathrm{a} \\
\mathrm{A}\end{array}$ & . & $2.26 \pm 0.07 \mathrm{aA}$ & $\begin{array}{c}0.17 \pm 0 . \\
01 \mathrm{a}\end{array}$ & - & $\begin{array}{c}1.78 \pm 0.05 \\
\mathrm{aA}\end{array}$ & $\begin{array}{c}2.08 \pm 0 \\
05 \mathrm{aA}\end{array}$ & $\begin{array}{c}3.36 \pm 0.06 \mathrm{a} \\
\mathrm{A}\end{array}$ & $\begin{array}{c}12.23 \pm 0 . \\
55 \mathrm{aA}\end{array}$ \\
\hline $\mathrm{T} 3$ & $\begin{array}{c}1.52 \pm 0.03 \mathrm{c} \\
\mathrm{C}\end{array}$ & 一 & $1.56 \pm 0.06 \mathrm{cC}$ & $\begin{array}{c}0.16 \pm 0 . \\
00 \mathrm{a}\end{array}$ & - & $\begin{array}{c}0.77 \pm 0.04 \\
\mathrm{bB}\end{array}$ & $\begin{array}{c}0.81 \pm 0 \\
03 \mathrm{bB}\end{array}$ & $\begin{array}{c}1.72 \pm 0.05 \mathrm{c} \\
\mathrm{B}\end{array}$ & $\begin{array}{c}6.54 \pm 0.4 \\
3 \mathrm{cC}\end{array}$ \\
\hline
\end{tabular}

Note: values are means $\pm \mathrm{SD}(\mathrm{n}=5)$. Means in columns without letters in common differ significantly $(\mathrm{P}<0.05)$. ND $=$ not detected.

Table 3. The proximate content of non-essential amino acid in vinegars (mg/ L).

\begin{tabular}{|c|c|c|c|c|c|c|c|c|c|c|c|}
\hline $\begin{array}{c}\text { Trea } \\
\text { tmen } \\
t\end{array}$ & Asp & Ser & Gln & Gly & Ala & Cys & Tyr & His & Arg & Pro & Total \\
\hline $\mathrm{T} 1$ & $\begin{array}{l}1.32 \pm 0 \\
05 \mathrm{cC}\end{array}$ & $\begin{array}{l}1.83 \pm 0 \\
06 \mathrm{cC}\end{array}$ & $\begin{array}{l}1.10 \pm 0 . \\
06 \mathrm{bB}\end{array}$ & $\begin{array}{l}0.36 \pm 0.0 \\
4 \mathrm{cC}\end{array}$ & $\begin{array}{l}4.40 \pm \\
0.40 \mathrm{c} \\
\mathrm{C}\end{array}$ & $\begin{array}{l}1.03 \\
\pm 0.0 \\
0 \mathrm{a}\end{array}$ & $\begin{array}{l}0.70 \pm 0 . \\
00 \mathrm{bB}\end{array}$ & $\begin{array}{l}0.62 \pm 0 \\
00 \mathrm{bB}\end{array}$ & $\begin{array}{l}0.34 \pm 0 \\
00 \mathrm{bB}\end{array}$ & $\begin{array}{l}1.31 \pm 0.0 \\
2 \mathrm{cC}\end{array}$ & $\begin{array}{l}13.01 \\
\pm 0.09 \\
\mathrm{cC}\end{array}$ \\
\hline $\mathrm{T} 2$ & $\begin{array}{l}44.56 \pm 3 \\
.51 \mathrm{aA}\end{array}$ & $\begin{array}{l}9.48 \pm 0 \\
09 \mathrm{aA}\end{array}$ & $\begin{array}{l}4.54 \pm 0 . \\
57 \mathrm{aA}\end{array}$ & $\begin{array}{l}1.94 \pm 0.0 \\
8 \mathrm{aA}\end{array}$ & $\begin{array}{l}29.64 \\
\pm 1.10 \\
\mathrm{aA}\end{array}$ & $\begin{array}{l}1.14 \\
\pm 0.0 \\
0 \mathrm{a}\end{array}$ & $\begin{array}{l}1.24 \pm 0 \\
05 \mathrm{aA}\end{array}$ & $\begin{array}{l}1.60 \pm 0 \\
04 \mathrm{aA}\end{array}$ & $\begin{array}{l}0.65 \pm 0 \\
03 a A\end{array}$ & $\begin{array}{l}93.06 \pm 3 . \\
95 \mathrm{aA}\end{array}$ & $\begin{array}{l}187.8 \\
5 \pm 6.7 \\
7 \mathrm{aA}\end{array}$ \\
\hline
\end{tabular}




\begin{tabular}{|c|c|c|c|c|c|c|c|c|c|c|c|}
\hline $\mathrm{T} 3$ & $\begin{array}{l}10.02 \pm 0 \\
.08 \mathrm{bB}\end{array}$ & $\begin{array}{l}2.61 \pm 0 . \\
13 \mathrm{bB}\end{array}$ & $\begin{array}{l}1.18 \pm 0 . \\
04 \mathrm{bB}\end{array}$ & $\begin{array}{l}0.56 \pm 0.0 \\
6 \mathrm{bB}\end{array}$ & $\begin{array}{l}7.12 \pm \\
0.10 \mathrm{~b} \\
\text { B }\end{array}$ & $\begin{array}{l}1.02 \\
\pm 0.0 \\
1 \mathrm{a}\end{array}$ & $\begin{array}{l}0.78 \pm 0 . \\
02 \mathrm{bB}\end{array}$ & $\begin{array}{l}0.62 \pm 0 . \\
01 \mathrm{bB}\end{array}$ & $\begin{array}{l}0.32 \pm 0 . \\
00 \mathrm{bB}\end{array}$ & $\begin{array}{l}17.52 \pm 1 \\
55 \mathrm{bB}\end{array}$ & $\begin{array}{l}41.75 \\
\pm 2.33 \\
\text { bB }\end{array}$ \\
\hline
\end{tabular}

Note: values are means $\pm \mathrm{SD}(\mathrm{n}=5)$. Means in columns without letters in common differ significantly $(\mathrm{P}<0.05)$. ND $=$ not detected.

In minerals and microelements part, $\mathrm{T} 1$ has the highest contents $\mathrm{Fe}(3.30 \mathrm{mg} / \mathrm{L}), \mathrm{Mg}(85.40 \mathrm{mg} / \mathrm{L}), \mathrm{Zn}(1.10 \mathrm{mg} / \mathrm{L})$ and $\mathrm{Ca}(150.00 \mathrm{mg} / \mathrm{L})$ shown that the vinegar included abundant mineral materials, and the characteristic constituent is the highest $\mathrm{Mg}$ and $\mathrm{Ca}$ contents (Table 1). Treatment T2 has the highest contents protein $(0.52 \mathrm{mg} / \mathrm{L}), 2800.00 \mathrm{mg} / \mathrm{L} \mathrm{Na}$ and $123.00 \mathrm{mg} / \mathrm{L} \mathrm{P}$, so the characteristic constituent are $\mathrm{Na}$ and P contents that these was difference than T1 (Table 1). However, Treatment $\mathrm{T} 3$ falls in between (Table 1).

\subsection{The content different of essential amino acid}

The total content of essential amino acid was lower among three treatments, and the amino acid Trp was not found in this paper (Table 2). The total content of essential amino acid from highest to lowest at different treatments was T2, T3 and T1. Treatment $\mathrm{T} 1$, have the only amino acid $\mathrm{Thr}(1.11 \mathrm{mg} / \mathrm{L})$ and lowest total essential amino acid. Treatment $\mathrm{T} 2$ have the highest total essential amino acid $(12.23 \mathrm{mg} / \mathrm{L})$, and the components of amino acid Lys $(2.58 \mathrm{mg} / \mathrm{L})$, Phe $(2.26 \mathrm{mg} / \mathrm{L})$, Ile $(1.78 \mathrm{mg} / \mathrm{L})$, Leu $(2.08 \mathrm{mg} / \mathrm{L})$ and $\mathrm{Val}(3.36 \mathrm{mg} / \mathrm{L})$ also has highest and the difference reached very significant Table 2$)$. The T3 falls in the between except amino acid Leu and total essential amino acid (Table 2).

\subsection{The content different of non-essential amino acid}

The content tendency of total content of non-essential amino acid shown the same rule with essential amino acid, the contents from highest to lowest was $\mathrm{T} 2>\mathrm{T} 3>\mathrm{T} 1$ (Table 3), but the every constituents were significant difference. Treatment T2, not only have the highest total content but also have the highest constituents $(44.56 \mathrm{mg} / \mathrm{L}$ Asp, $9.48 \mathrm{mg} / \mathrm{L}$ Ser, $4.54 \mathrm{mg} / \mathrm{L} \mathrm{Gln}, 29.64 \mathrm{mg} / \mathrm{L}$ Ala, $1.24 \mathrm{mg} / \mathrm{L}$ Tyr and $0.65 \mathrm{mg} / \mathrm{L} \mathrm{Arg}$ ), especially in the content of amino acid Pro that reached to the $93.06 \mathrm{mg} / \mathrm{L}$, the higher over 71, 5.3 times, respectively. And the next is the Asp, the difference reached to the 33.8, 4.5 times, respectively. So, the contents of amino acid Pro and Asp were the typical compositions in T2.

\section{Conclusion and discussion}

We have developed three new vinegar types. Vinegar prepared from Prunus armeniaca $\times$ P. sibirica cultivar Zhongren No.1 (T1) fruit pulp is a novel beverage rich minerals and microelements, especially in contents of $\mathrm{Fe}, \mathrm{Mg}, \mathrm{Zn}$ and $\mathrm{Ca}$, so we putative that the content minerals $\mathrm{Ca}$ is the typical characteristic. Vinegar prepared from Prunus domestica $\times P$. armeniaca cultivar Fengweimeigui (T2) fruit pule is a novel beverage rich amino acid $(200.08 \mathrm{mg} / \mathrm{L})$, especially in non-essential amino acid $(187.85 \mathrm{mg} / \mathrm{L})$, and this is the typical characteristic. But treatment $\mathrm{T} 3$, the contents of minerals, microelements and amino acids fall in between $\mathrm{T} 1$ and $\mathrm{T} 2$, the characteristic is mild and the nutrient is balanced.

In this study, the vinegars of proteins, fats and non-essential amino acid were lower than kernel-apricot vinegar, but the essential amino acid was significant higher, especially amino acid Lys, Phe, Met, Leu and Val, meanwhile, the amino acid Thr, Ile, Gln and Arg were only found in apricot vinegars [3], the results showed that the fermenting method was importance factor for nutritional ingredient separation from fruits pulp. Compared with apple vinegar, the essential amino acid was significant lower, but non-essential amino acid including the Ser, Ala and Pro were higher [11], especially the amino acid Pro (Table 3, $93.06 \mathrm{mg} / \mathrm{L}$ ) was the over 180 times than apple vinegar $(0.50 \mathrm{mg} / \mathrm{L})$. Compared with persimmon vinegar, the amino acid was significant higher than persimmon vinegar [12], and the amino acid Cys was not found. 


\section{Acknowledgments}

This work was supported by the Program of Research and Demonstration of Key Technology of High-efficient Production in Kernel-apricot and Almond under Grant No. 2013BAD14B02.

\section{References}

1. L.L. Lei, Study on the reproductive biology of Prunus domestica $\times$ armeniaca 'fengweimeigui', M.S. Thesis, Chinese Academy of Forestry, Beijing, China (2013).

2. G.P. Zhu, H. Zhao, X.X. Zhou, M.P. Liu, Y.L. Huang, T.N. Wuyun, F.D. Li, Prunus domestica $\times$ P. armeniaca cultivar Fengweimeigui: A New Natural Material for Fruit Wine, Adv. J. Food Sci. Technol. 10(4), 277-280 (2016).

3. Y. Fan, Studies on the brewing techniques of apricot for kernel flesh vinegar and its health-care function, M.S. Thesis, Northwest A\&F University, Yangling, China (2008).

4. S.M. Araújo, C.F. Silva, J.J.S. Moreira, N. Narain, R.R. Souza, Biotechnological process for obtaining new fermented products from cashew apple fruit by Saccharomyces cerevisiae strains, J. Ind. Microbiol. Biotechnol. 38, 1161-1169 (2011).

5. T.S. Suryanarayanan, N. Thirunavukkarasu, M.B. Govindarajulu, V. Gopalan, Fungal endophytes: an untapped source of biocatalysts, Fungal Diversity 54, 19-30 (2012).

6. Y. Jiang, S. Lin, L. Zhang, P. Yu, Upgrading the Fermentation Process of Zhejiang Rosy Vinegar by Purebred Microorganisms, Advances in Microbiology 3, 297-301 (2013).

7. Z Nie, Y. Zheng, H. Du, S. Xie, M. Wang, Dynamics and diversity of microbial community succession in traditional fermentation of Shanxi aged vinegar, Food Microbiology 47, 62-68 (2015).

8. J. Qui, C. Ren, J. Fan, Z. Li, Antioxidant activities of aged oat vinegar in vitro and in mouse serum and liver, Journal of the science and food agriculture 90, 1951-1958 (2010).

9. World Health Organization, Obesity and overweight, Available from http://www.who.int/mediacentre/factsheets/fs311/en/ (2015).

10. C.H. Chou, C.W. Liu, D.J. Yang, Y.H. Samuel, Y.C. Wu, Chen, Amino acid, mineral, and polyphenolic profiles of black vinegar and its lipid lowering and antioxidant effects in vivo, Food Chemistry 168, 63-69 (2015).

11. H.T. Zhang, X.L. Liu, Development and amino acid analysis of apple cider vinegar drink. Journal of Shandong Institute of Light Industry 24(1), 41-44. (2010) (in Chinese).

12. X.L. Luo, Y. Yang, S.M. Lu, C.L. Zhang, The impact of fermentation modes on sensory and nutritional quality of persimmon $\quad$ vinegar, Food $\quad$ Science, Available from http://www.cnki.net/kcms/detail/11.2206.TS.20160108.1651.052.html (2016) (in Chinese) (to be published online). 